
медичний університет”, м. Чернівці

\title{
ЕФЕКТИВНІСТЬ МЕТОДУ “ДІЛОВА ГРА” НА ЗАНЯТТЯХ 3 АПТЕЧНОЇ ТЕХНОЛОГІЇ ЛІКАРСЬКИХ ЗАСОБІВ
}

\author{
V. H. Zeleniuk, O. M. Horoshko, O. Iu. Tkachuk \\ Bukovynian State Medical University, Chernivtsi

\section{THE EFFICIENCY OF THE “BUSINESS GAME” METHOD IN CLASSES IN THE PHARMACEUTICAL TECHNOLOGY OF MEDICINES}

\begin{abstract}
Мета роботи - вивчити ефективність удосконалення навчального процесу з використанням інтерактивного методу навчання - ділової гри.

Основна частина. У статті описано досвід застосування методу активізації навчально-пізнавальної діяльності - ділової гри - на практичних заняттях із аптечної технології лікарських засобів для студентів спеціальності “Фармація”. Результати аналізу рівня знань студентів на початку та по завершенні дослідження продемонстрували переваги та недоліки впровадження ділової гри у навчально-педагогічний процес.

Висновок. Застосування ділової гри підвищує засвоюваність студентами практичних навичок та теоретичного матеріалу дисципліни при зниженні ефективності методу за його безперервного використання.

Ключові слова: ділова гра; аптечна технологія лікарських засобів; інтерактивні методи навчання.

The aim of the work - to evaluate the effectiveness of the educational process' improvement using the interactive method of training - a business game.

The main body. The article describes the experience of using the educational-cognitive efforts' activation method - the business game - in practical classes in the pharmaceutical technology of medicines for the pharmaceutical students. The results of the analysis of the students' knowledge level at the beginning and at the end of the study has shown the advantages and disadvantages of implementation the business game method in the educational and pedagogical process.

Conclusion. The use of the business game increases the absorption of practical skills and discipline's theoretical material by the students with reduction in the effectiveness of the method in association with its permanent use.
\end{abstract}

Key words: business game; pharmaceutical technology of medicines; interactive teaching methods.

Вступ. Аптечна технологія лікарських засобів (АТЛЗ) - глибоко практично-орієнтована дисципліна. Відпрацювання практичних навичок на заняттях є вкрай необхідним для засвоєння студентами професійних вмінь [1]. Як демонструють результати досліджень, студенти краще засвоюють практичні навички на заняттях із залученням методів активізації навчально-пізнавальної діяльності [24]. Завдяки останнім можна підвищити у студентів пізнавальний інтерес, активність, творчість, самостійність в одержанні знань та формуванні вмінь, використання їх на практиці $[5,6]$. Для занять 3 АТЛЗ найбільш підхожим серед таких методів $є$ ділова гра, яка являє собою форму відтворення предметного і соціального змісту майбутньої про-

(․ В. Г. Зеленюк, О. М. Горошко, О. Ю. Ткачук фесійної діяльності фахівця, моделювання таких систем відносин, які характерні для цієї діяльності як цілого [7, 8]. Ділова гра спрямована на те, щоб, імітуючи реальні професійні ситуації та виконуючи “справжні”, а не “навчальні” ролі, студенти набували умінь та навичок, необхідних для виконання різних видів практичної діяльності [9]. Це сприяє розвитку продуктивного мислення студентів в умовах, максимально наближених до реальних.

При всіх своїх сильних сторонах ділова гра має і недоліки: трудомісткість та ресурсовитратність підготовки, захоплюваність зовнішньою стороною ролі, складність об'єктивного оцінювання студента, заздалегідь передбачений результат, що знижує інтерес до гри [10]. У діловій грі не можна грати в те, про що студенти не мають уявлення, тобто ком- 
петентна їх участь у грі можлива тільки при наявності необхідних знань та попередньої підготовки. Тому необхідно встановити, чи можливо застосувати цей метод активізації навчально-пізнавальної діяльності для занять із АТЛЗ.

Мета роботи - вивчити ефективність удосконалення навчального процесу з використанням інтерактивного методу навчання - ділової гри.

Основна частина. Для дослідження обрали дві групи студентів зі схожими середніми балами за результатами атестації у вересні: I група - конт-

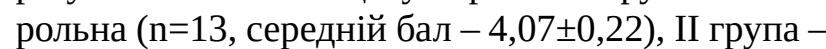

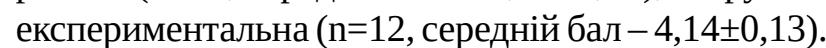
Дослідження проводили протягом одного місяця (жовтня): заняття І групи проводили за класичною методикою, а у II групі - із використанням методу ділової гри. В обох групах проводили вихідний та підсумковий тестовий контроль знань із кожної теми (всього 4 заняття на місяць), оцінювали виконання практичних навичок та порівнювали середні бали за результатами місячної атестації. Заняття проводили на кафедрі фармації Вищого державного навчального закладу України “Буковинський державний медичний університет”. Статистичну обробку результатів виконували із застосуванням непараметричного методу Вілкоксона - Манна Уїтні, різницю вважали вірогідною при $\mathrm{p} \geq 0,05$.

Практичні заняття з АТЛЗ у студентів обох груп проводять згідно з навчальним планом протягом 4-х академічних годин. У студентів I і II груп перші 2 години проводили за традиційною методикою, дотримуючись підготовчого, основного та заключного етапів. На першому етапі викладач окреслює тему заняття та мету, обгрунтовуючи їі значущість у майбутній професійній діяльності та мотивуючи студентів до її вивчення, розбирає зі студентами незрозумілі питання, які виникли при підготовці. На основному етапі здійснюється контроль вихідного рівня знань у формі тестування та індивідуального усного опитування з наступним закріпленням матеріалу шляхом виконання ситуаційних та розрахункових задач. На заключному етапі викладач здійснює корекцію рівня професійних знань та умінь, підводить підсумки заняття, аналізує відповіді студентів.

Наступні 2 години у досліджуваних групах проводилися по-різному: студенти I групи виготовляли лікарські форми (ЛФ) за рецептами, а студенти II групи брали участь у діловій грі. Заняття у кожній із двох груп завершувалися тестовим вихідним контролем рівня знань та оголошенням оцінок.
Методика проведенення заняття за методом ділової гри була розроблена згідно з навчально-методичним посібником “Психологія і педагогіка: Проведення індивідуального заняття за методом рольової гри” [9]. Проведення ділової гри включає такі етапи: перший, на якому викладається вихідна інформація, спільно визначаються завдання гри та розподіляються ролі; та другий, на якому учасники виконують рольові функції, наприкінці - студенти та викладач аналізують результати гри [6].

Студенти в групі розподілялись на дві підгрупи, у кожній з яких присвоювалися такі ділові ролі: провізор-рецептар, провізор-технолог (2-3 студенти), провізор-аналітик, фармінспектор. Провізоррецептар приймав рецепт, перевіряв правильність його виписування, норми відпуску ліків та їх вищі дози, записував у журнал обліку, виписував етикетки. Провізор-технолог здійснював розрахунки компонентів ЛФ, безпосередньо виготовляв препарат та оформляв його до відпуску. Провізор-аналітик проводив контроль якості препарату і занесення результатів у журнал. Студент у ролі фармінспектора виконував ділові обов'язки співробітника Державної служби України з лікарських засобів та контролю за наркотиками, а саме перевіряв виконання усіма учасниками гри своїх професійних обов'язків. Кожного наступного заняття студенти виконували різні ролі.

У ході гри студенти відпрацьовують усі практичні навички, передбачені робочою програмою 3 АТЛЗ. Викладач здійснює контроль над ходом гри, за необхідності коригує його та здійснює оцінювання кожної навички відповідно до розробленої шкали. Після приготування ЛФ “фармінспектор” оголошує результат “перевірки”, а викладач - бали, які набрали учасники. По завершенні основного завдання студентам, які залишаються у тих же ролях, пропонується виконати нетипові ситуаційні завдання. Підсумки заняття підводяться спільно усіма учасниками ділової гри.

Як показали результати вихідного тестового контролю знань, підготовка студентів обох досліджуваних груп до першого заняття була на одному рівні (табл. 1). Покращення результатів тестування у II групі на 2-3 заняттях (на 20 \% та 17 \% відповідно, порівняно із заняттям № 1) вказує на посилення зацікавленості студентів у підготовці до занять, у той час як у I групі показники вірогідно не змінились. У той же час зменшення показників у II групі на останньому занятті відображає спад інтересу до підготовки. 
Таблиця 1. Результати вихідного тестового контролю знань студентів

\begin{tabular}{|c|c|c|}
\hline Заняття & I група & II група \\
\hline № 1 & $3,92 \pm 0,21$ & $3,83 \pm 0,24$ \\
\hline № 2 & $3,92 \pm 0,18$ & $4,58 \pm 0,15^{* \#}$ \\
\hline № 3 & $3,85 \pm 0,15$ & $4,50 \pm 0,15^{* \#}$ \\
\hline № 4 & $4,00 \pm 0,20$ & $4,00 \pm 0,21$ \\
\hline
\end{tabular}

Примітка. * - різниця з групою контролю, * - різниця із заняттям № 1 .

Результати підсумкового контролю продемонстрували покращення знань у студентів II групи уже із першого заняття (на 17 \% порівняно із І групою), проте із падінням результатів на третьому та четвертому - на 16 \% порівняно із заняттям № 1 (табл. 2). Це підтверджує припущення щодо зменшення зацікавленості студентів в участі у діловій грі, яка, на їх думку, перетворюється в рутину. Оцінки у I групі були практично на одному рівні.

Таблиця 2. Результати підсумкового тестового контролю знань студентів

\begin{tabular}{|c|c|c|}
\hline Заняття & I група & II група \\
\hline № 1 & $3,92 \pm 0,21$ & $4,58 \pm 0,22^{*}$ \\
\hline № 2 & $4,08 \pm 0,15$ & $4,33 \pm 0,10$ \\
\hline № 3 & $4,00 \pm 0,20$ & $4,17 \pm 0,11$ \\
\hline № 4 & $4,15 \pm 0,22$ & $3,92 \pm 0,20^{\#}$ \\
\hline
\end{tabular}

Примітка. * - різниця з групою контролю, \# - різниця із заняттям № 1 .

Втім, незважаючи на наведені вище тендеції до падіння результатів підготовки студентів у II групі, результати жовтневої атестації показали підви-

\section{Список літератури}

1. Кириченко Л. М. Практичне навчання в системі підготовки майбутніх фахівців у фармацевтичному коледжі / Л. М. Кириченко // Збірник наукових праць “Педагогіка та психологія”. - Х., 2016. - Вип. 53. С. 192-200.

2. Андрєєва О. О. Дослідження успішності навчання та самооцінки активності студентів при удосконаленні викладання дисципліни “Клінічна фармація” / О. О. Андрєєва // Управління, економіка та забезпечення якості в фармації. - 2014. - № 5 (37). - С. 41-45.

3. Randi M. A. F. Learning through role-playing games: an approach for active learning and teaching / M. A. F. Randi, H. F. de Carvalho // Revista Brasileira De Educação Médica. 2013. - No. 37 (1). - P. 80-88.

4. The use of multiple-criteria decision-making theory to measure students' perceptions of high-fidelity simulation / M. A. Jersby, P. Van-Schaik, S. Green [et al.] // BMJ Simulation and Technology Enhanced Learning. - 2017. No. 3. - P. 88-93. щення середнього бала в досліджуваних студентів (табл. 3). Аналогічно виріс і показник засвоєння практичних навиків студентами II групи (на \%) при відсутності змін у студентів I групи.

Отже, як продемонстрував досвід впровадження цієї форми навчання, студенти цільової групи краще засвоювали матеріал порівняно із групою контролю. В загальному, це виражалось у підвищенні місячного атестаційного середнього бала в II групі на 3 \% та збільшенні кількості правильних відповідей на тестові завдання на 8 \%. При цьому описане вище падіння результатів у II групі порівняно із початком місяця ілюструє зменшення інтересу студентів до занять. Воно може бути викликане повторюваністю та штучністю створених ситуацій, підвищенням легковажного ставлення зі сторони учасників.

Таблиця 3. Результати підсумкової місячної атестації та оцінювання практичних навиків

\begin{tabular}{|c|c|c|c|c|}
\hline \multirow{2}{*}{ Місяць } & \multicolumn{2}{|c|}{ Середній бал } & \multicolumn{2}{c|}{ Практичні навики } \\
\cline { 2 - 5 } & I група & II група & I група & II група \\
\hline Вересень & $4,07 \pm 0,22$ & $4,14 \pm 0,13$ & $3,92 \pm 0,18$ & $3,83 \pm 0,17$ \\
\hline Жовтень & $4,04 \pm 0,18$ & $4,25 \pm 0,15$ & $4,00 \pm 0,16$ & $4,42 \pm 0,15 *$ \\
\hline
\end{tabular}

Примітка. * - різниця з групою контролю.

Висновки. Застосування методу активізації навчально-пізнавальної діяльності студентів “ділова гра” підвищує засвоюваність ними практичних навичок та теоретичного матеріалу дисципліни. Втім, безперервне використання зазначеного методу призводить до зниження його ефективності.

5. Рибак Н. І. Методи активізації навчально-пізнавальної діяльності студентів [Електронний ресурс] / H. I. Рибак. - Режим доступу до ресурсу : http://osvita.ua/ school/lessons_summary/edu_technology/13690/.

6. Дорошкевич I. О. Використання інтерактивних методів навчання серед студентів фармацевтичного факультету / I. О. Дорошкевич // Клінічна та експериментальна патологія. - 2015. - T. XIV, № 4 (54). - С. 231-233.

7. Харжевська О. М. Ділова гра як один із ефективних сучасних методів навчання у вищій школі / О. М. Харжевська // Материали за 7-а Международна научна практична конференция “Achivement of high school”. - София (България) : Бял ГРАД-БГ, 2011. - Т. 20 : Педагогически науки. - С. 66-68.

8. Довженко I. Роль ділової гри у професійній підготовці майбутніх фахівців сфери обслуговування / I. Довженко // Педагогіка і психологія професійної освіти. - 2013. - № 6. - С. 96-103. 
9. Дзеньдзюра Н. І. Психологія і педагогіка. Проведення індивідуального заняття за методом рольової гри : навч.-метод. посіб. / Н. І. Дзеньдзюра. - Львів : ЛІБС УБС НБУ, 2013. - 38 с.

\section{References}

1. Kyrychenko, L.M. (2016). Praktychne navchannia v systemi pidhotovky maibutnikh fakhivtsiv u farmatsevtychnomu koledzhi [Practical training in the system of training of future specialists in the pharmaceutical college]. Zbirnyk naukovykh prats "Pedahohika ta psykholohiia" - Collection of Scientific Works "Pedagogy and Psychology”, 53, 192-200 [in Ukrainian].

2. Andrieieva, O.O. (2014). Doslidzhennia uspishnosti navchannia ta samootsinky aktyvnosti studentiv pry udoskonalenni vykladannia dystsypliny "Klinichna farmatsiia" [Study of the success of training and selfassessment of students' activity in the improving of the teaching of the discipline "Clinical Pharmacy"]. Upravlinnia, ekonomika ta zabezpechennia yakosti $v$ farmatsii - Management, Economics and Quality Assurance in Pharmacy, 5 (37), 41-45 [in Ukrainian].

3. Randi, M.A.F., \& de Carvalho, H.F. (2013). Learning through role-playing games: an approach for active learning and teaching. Revista Brasileira De Educação Médica. 37 (1), 80-88.

4. Jersby, M.A., Van-Schaik, P., \& Green, S. (2017). The use of multiple-criteria decision-making theory to measure students' perceptions of high-fidelity simulation. BMJ Simulation and Technology Enhanced Learning, 3, 88-93.

5. Rybak, N.I. Metody aktyvizatsii navchalno-piznavalnoi diialnosti studentiv [Methods of activation of educational and cognitive activity of students]. Retrieved from: ttp:// osvita.ua/school/lessons_summary/edu_technology/13690/ [in Ukrainian].

6. Doroshkevych, I.O. (2015). Vykorystannia interaktyvnykh metodiv navchannia sered studentiv farma-
10. Макарцева Л. В. Применение деловых игр в высшем образовании / Л. В. Макарцева, В. Д. Макарцева // Образование в современном мире : сб. науч. ст. / под ред. Ю. Г. Голуба. - 2015. - С. 169-171.

tsevtychnoho fakultetu [Use of interactive teaching methods among the pharmaceutical students]. Klinichna ta eksperymentalna patolohiia - Clinical and Experimental Pathology. XIV, 4 (54), 231-233 [in Ukrainian].

7. Kharzhevska, O.M. (2011). Dilova hra yak odyn iz efektyvnykh suchasnykh metodiv navchannia u vyshchii shkoli [Business game as one of the most effective modern teaching methods in a high school]. Materialy za 7-a mezhdunarodna nauchna praktychna konferentsyya "Achivement of high school" - Materials for the 7th International Scientific Practical Conference "Achivement of high school”. 20. 66-68. Sofiia (Bolhariia): Bial HRAD-BH [in Ukrainian].

8. Dovzhenko, I. (2013). Rol dilovoi hry u profesiinii pidhotovtsi maibutnikh fakhivtsiv sfery obsluhovuvannia [The role of business game in the training of future professionals in the service sector]. Pedahohika i psykholohiia profesiinoi osvity - Pedagogy and Psychology of Vocational Education, 6, 96-103 [in Ukrainian].

9. Dzendziura, N.I. (2013). Psykholohiia i pedahohika. Provedennia indyvidualnoho zaniattia za metodom rolovoi hry: navchalno-metodychnyi posibnyk [Psychology and pedagogy. Teaching an individual class by the role-playing method: a teaching guide]. Lviv: LIBS UBS NBU [in Ukrainian].

10. Makartseva, L.V., \& Makartseva, V.D. (2015). Primenenie delovykh igr v vysshem obrazovanii [Application of business games in higher education]. Obrazovanie $v$ sovremennom mire: Sbornik nauchnykh statey - Education in the Modern World: Collection of Scientific Articles, 169-171 [in Russian]. 